\title{
Spill-over from aquaculture may provide a larval subsidy for the restoration of mussel reefs
}

\author{
Craig Norrie ${ }^{1,6, *}$, Brendon Dunphy ${ }^{1,2}$, Moninya Roughan ${ }^{3}$, Simon Weppe ${ }^{4}$, \\ Carolyn Lundquist ${ }^{1,5}$ \\ ${ }^{1}$ Institute of Marine Science, University of Auckland, Auckland 1010, New Zealand \\ ${ }^{2}$ School of Biological Sciences, University of Auckland, Auckland 1010, New Zealand \\ ${ }^{3}$ School of Mathematics and Statistics, UNSW Sydney, NSW 2052, Australia \\ ${ }^{4}$ Meteorological Service of New Zealand (MetOcean Division), Raglan 3225, New Zealand \\ ${ }^{5}$ National Institute of Water and Atmospheric Research (NIWA), Hamilton 3216, New Zealand \\ ${ }^{6}$ Present address: Hatfield Marine Science Center, Cooperative Institute for Marine Resources Studies, \\ Oregon State University, Newport, OR 97365, USA
}

\begin{abstract}
Worldwide bivalve aquaculture is expanding rapidly. Simultaneously, there has been a loss of natural bivalve reefs due to anthropogenic activities. As bivalve reefs support several ecosystem functions disproportionate to the area they cover, there is interest in their restoration. The Firth of Thames (FoT) in northern New Zealand once supported dense populations of green lipped mussels Perna canaliculus, which were extirpated by a dredge fishery in the mid- $20^{\text {th }}$ century. Efforts to restore these biogenic habitats are underway. The largest standing populations of this species in the area currently exist in aquaculture. This study aimed to determine if larval spill-over from aquaculture can provide a larval subsidy to bivalve reef restoration efforts in the FoT. We used a combination of trace elemental fingerprinting and biophysical modelling techniques to determine patterns of larval dispersal in the area. Results of both approaches indicated that the larval pool in the area is well mixed with larvae produced at aquaculture locations capable of settling throughout the study area. Overall this shows, for the first time, that larval spill-over from aquaculture may provide a subsidy to restoration efforts and assist with establishing sustainable populations. When determining restoration locations, the potential for aquaculture populations to act as a larval source should be explicitly considered. Conversely, when considering the location of new aquaculture sites, the consequences of larval spill-over to surrounding wild populations should be assessed. We recommend that restoration efforts and aquaculture be carefully integrated in a network approach which could provide both ecological and economic benefits.
\end{abstract}

KEY WORDS: Larval dispersal · Population connectivity · Bivalve larvae · Biophysical modelling · Trace elemental fingerprinting $\cdot$ Restoration $\cdot$ OpenDrift $\cdot$ Shell chemistry

\section{INTRODUCTION}

At a global scale, coastal shellfish aquaculture is rapidly expanding in order to help meet the protein needs of a growing human population (FAO 2018). As cultured biomass of shellfish increases, it will inevitably affect ecosystem dynamics in the local area in which this culturing is taking place (van der Schatte

${ }^{*}$ Corresponding author: craig.norrie@oregonstate.edu
Olivier et al. 2020). These aquaculture-environment interactions may be perceived as either negative or positive. Effects viewed as negative may include the organic enrichment of the benthos through biodeposits (Giles \& Pilditch 2006, Cranford et al. 2009), alteration of the genetic composition of populations through the escape of larvae or adults (Gausen \& Moen 1991, Apte et al. 2003, Heino et al. 2015), or the

(C) The authors 2020. Open Access under Creative Commons by Attribution Licence. Use, distribution and reproduction are unrestricted. Authors and original publication must be credited. 
alteration of flow regimes by the structures on which aquaculture is taking place (Gibbs et al. 1991, Plew 2011). Effects perceived as positive may involve nutrient remediation in eutrophied systems (Petersen et al. 2014, Nielsen et al. 2016) or providing habitat for other species (McLeod et al. 2014, Fariñas-Franco \& Roberts 2018). Although often overlooked in studies investigating the effects of aquaculture on the local environment (see reviews by Newell 2004, van der Schatte Olivier et al. 2020), larval production from these dense aggregations of bivalves may contribute to regional larval pools and thereby modify population dynamics in the area in which they are growing. Knowledge of potential larval dispersal pathways from these cultured populations is essential to gain an understanding of how larvae from aquaculture may interact with local wild bivalve populations. Understanding these interactions is of particular interest in areas where natural populations of bivalves have been depleted but cultured populations exist; e.g. the Firth of Thames (FoT) in northern New Zealand for green lipped mussel or Chesapeake Bay for Virginia oysters (Beck et al. 2011, Turner et al. 2019).

Shellfish beds perform a number of ecosystem functions disproportionate to their size (Lundquist et al. 2017). They contribute to water filtration (zu Ermgassen et al. 2013, Ehrich \& Harris 2015), nutrient cycling (Giles \& Pilditch 2006, Nielsen et al. 2016), provide habitat structure (Dumbauld et al. 2009), and can influence food web dynamics and biodiversity (McLeod et al. 2014, Fariñas-Franco \& Roberts 2018). However, several common anthropogenic stressors are recognised worldwide which have resulted in degradation or removal of these biogenic habitats with a corresponding loss of ecosystem functions (Beck et al. 2011, Alleway \& Connell 2015). These stressors include sedimentation, eutrophication, overfishing, and dredging. Accordingly, there is interest in restoring degraded populations and the ecosystem functions they provide (e.g. French McCay et al. 2003, Coen et al. 2007, North et al. 2010). In order for restoration programmes to have the highest chances of success, an understanding of larval dispersal and population connectivity is essential (Lipcius et al. 2008). Understanding larval dispersal dynamics allows us to determine the selfsustainability of restored populations and also select optimal restoration locations (Elsäßer et al. 2013, Tettelbach et al. 2013, Puckett et al. 2018).

Although it is important to track the dispersal of larvae, in situ tracking of larval movement is complex due to the small size, high mortality, and large scales over which larval transport is possible (Gawarkiewicz et al. 2007, Cook et al. 2014). Thus, several techniques have been developed which allow larval dispersal and population connectivity to be indirectly inferred (reviewed by Kool et al. 2013). Currently, biophysical models (e.g. Cowen et al. 2000, Werner et al. 2007, Elsäßer et al. 2013, Thomas et al. 2016) and trace elemental fingerprinting (e.g. Thorrold et al. 2002, Becker et al. 2007, Ricardo et al. 2015, Gomes et al. 2016) are among the most widely applied techniques used to infer the dispersal of larvae. Biophysical modelling couples oceanographic data (e.g. ocean currents and temperature) with information on the biology and behaviour of larvae to estimate larval dispersal over spatial and temporal scales that would be impossible to measure empirically. Biophysical models have been used in a number of management scenarios, such as the design of marine reserves (Puckett et al. 2014), examining larval export from marine reserves (Le Port et al. 2014), determining restoration locations (Tettelbach et al. 2013, Puckett et al. 2018), predicting the spread of invasive species (Inglis et al. 2006), and projecting changes under future climate scenarios (Cetina-Heredia et al. 2015, Coleman et al. 2017). Trace elemental fingerprinting is based on the premise that carbonate structures such as shell or otolith deposited in water masses with differing physiochemical properties reflect these differences in the trace elemental composition of these structures (e.g. Cathey et al. 2012, Kroll et al. 2016, Norrie et al. 2019). Through the sequential analysis of these structures, the movement of individuals can be inferred (e.g. Lazareth et al. 2003, Kroll et al. 2018).

Each method of indirectly estimating larval dispersal, however, comes with intrinsic uncertainties (Ashford et al. 2010, Nolasco et al. 2018). Biophysical particle tracking models, for example, are limited by the availability and accuracy of the hydrodynamic and biological data used in their parameterisation (Cetina-Heredia et al. 2019). In contrast, trace elemental fingerprinting may be limited by the characterisation of all potential natal locations (Werner et al. 2007). Therefore, the incorporation of larval dispersal estimates obtained though different methods is likely to provide a more accurate picture of larval dispersal. Here, we incorporated results from both trace elemental fingerprinting and biophysical models to track the dispersal of green lipped mussels Perna canaliculus (Gmelin, 1791), hereafter mussels, in the FoT in northern New Zealand, an area with an active shellfish restoration effort (Wilcox et al. 2018). 
The FoT once supported dense populations of mussels, which were estimated to cover up to $1300 \mathrm{~km}^{2}$; these were almost completely extirpated by a dredge fishery in the 1960s (Paul 2012). Despite the cessation of fishing $50 \mathrm{yr}$ ago, these populations have not recovered and only a few small remnant wild mussel beds remain, which cover an area of approximately $0.64 \mathrm{~km}^{2}$ (Morrison 2002, McLeod 2009). Currently, the largest populations of mussels in the FoT are those farmed on longline aquaculture, which covers an area of approximately $29 \mathrm{~km}^{2}$ and produced 27196 t of harvested mussels in 2016 (Hauraki Gulf Forum 2017). There are currently active restoration efforts in the area which focus on the translocation of adults and juveniles, primarily from aquaculture, with the aim of establishing self-sufficient populations and recovering lost ecosystem function (Wilcox et al. 2018). Understanding the potential for larval spill-over from aquaculture to contribute to restoration efforts will provide important information for the design of restoration programmes in areas where aquaculture is present, as it will inform locations for mussel translocations.

The aim of this study was to examine the potential for larval spill-over of mussels from aquaculture to provide a larval subsidy to the restoration efforts in the FoT. This was achieved using a combination of elemental fingerprinting techniques and biophysical modelling approaches. We addressed the following specific questions: (1) What is the potential for dispersal of mussles from aquaculture locations throughout the FoT? (2) How do larval dispersal patterns generated by 2 different methods, biophysical modelling and trace elemental fingerprinting, differ? (3) What are the overall implications of any larval spill-over for restoration and aquaculture?

\section{MATERIALS AND METHODS}

\subsection{Study species}

Green lipped mussels Perna canaliculus are found in a variety of habitats throughout New Zealand, both subtidally and intertidally (Morton \& Miller 1973). Mussels are broadcast spawners with peak spawning occurring from late in the austral spring to early autumn (Alfaro et al. 2001), have a pelagic larval duration of between 3 and 5 wk (Hayden 1995), and prefer to settle on filamentous substrates such as macroalgae and hydroids (Alfaro \& Jeffs 2002, Alfaro et al. 2004). Settlement is complete once byssal threads have attached, after which mussels are known as plantigrades or spat. Secondary settlement may then occur through bysso-pelagic drifting from primary settlement substrate into adult beds (Jeffs et al. 1999). The distances over which secondary dispersal takes place, however, is likely to be orders of magnitude lower than primary dispersal in the plankton (Lane et al. 1985, Le Corre et al. 2013, Pilditch et al. 2015).

\subsection{Study area}

The FoT is a large estuarine embayment in north eastern New Zealand, approximately $30 \mathrm{~km}$ long and $20 \mathrm{~km}$ wide (Fig. 1). Circulation in the region is tidally driven and predominantly flows north-south, with current speeds on the ebb and flood tides generally well balanced (Supplement 1 at www.int-res. com/articles/suppl/q012p231_supp.pdf [all supplements], Black et al. 2000). East-west flows also occur but are typically around 10 times weaker than the north-south currents (Oldman et al. 2007). The FoT is generally thought to be well mixed with limited seasonal stratification in late summer (Black et al. 2000, Zeldis et al. 2005). Primary freshwater inputs are from the Waihou and Piako Rivers, which drain into the south eastern FoT. These rivers have a combined mean flow of $89 \mathrm{~m}^{3} \mathrm{~s}^{-1}$ (O'Callaghan \& Stevens 2017). The area zoned for mussel aquaculture occupies an area of $29 \mathrm{~km}^{2}$ and accounts for $30 \%$ of New Zealand's Greenshell ${ }^{\mathrm{TM}}$ (the trade name of $P$. canaliculus) mussel production (Hauraki Gulf Forum 2017). These farms are primarily located on the northern end of the Coromandel Peninsula centred on Wilson Bay. There are additional farms located within and around Coromandel Harbour and Manaia Harbour and on the western FoT at Waimang Point.

\subsection{Biophysical particle tracking}

\subsubsection{Hydrodynamic model}

An 11 yr (1995-2005) hindcast hydrodynamic model configuration of the regional ocean modelling system (ROMS), developed by the Meteorological Service of New Zealand (MetOcean Division), was used in this study. For a full description of this model and its validation, see Supplement 1 . Briefly, the model has a spatial grid resolution of $250 \times 250 \mathrm{~m}$ over the study area, with hourly model output. Both atmospheric and tidal forcing were included in the 


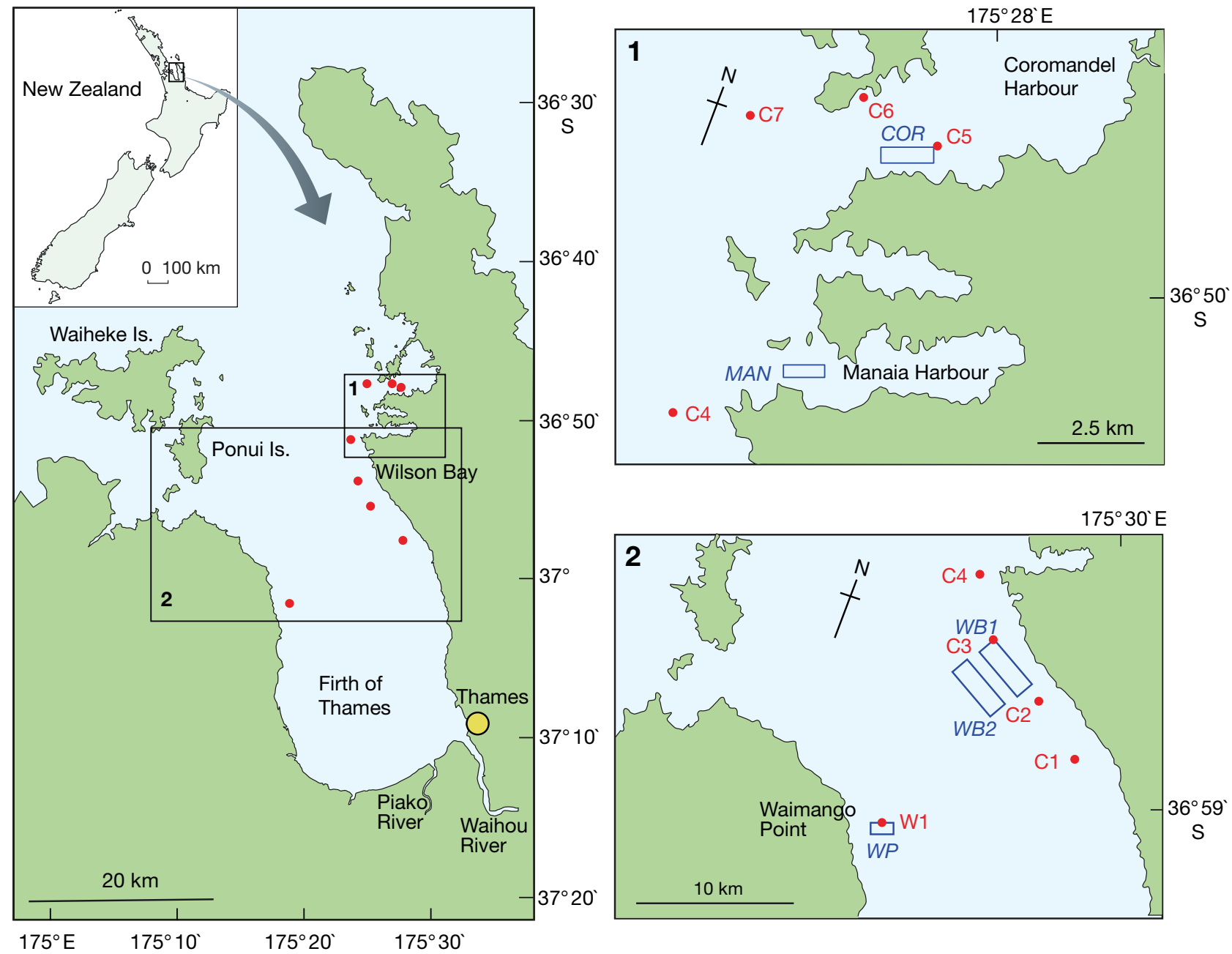

Fig. 1. The Firth of Thames in northern New Zealand, indicating sites used in this study. Blue rectangles: locations from which particles were released for biophysical modelling; red points: locations at which trace elemental fingerprinting sampling of Perna canaliculus was undertaken

model, which used bathymetry sourced from Land Information New Zealand (https://data.linz.govt.nz/layer/ 51278-chart-nz-533-firth-of-thames/). Atmospheric forcing was applied at a temporal resolution of $60 \mathrm{~min}$ and spatial resolution of $1 \mathrm{~km}$. Due to the limited stratification in the FoT (Black et al. 2000, Zeldis et al. 2005), a 2-dimensional approach was used which was followed by a post-process transformation to obtain estimates of the depth-dependent currents. A logarithmic velocity profile was added to depth-averaged currents to simulate variations in horizontal water flow (Le Port et al. 2014). This high-resolution model was nested within a larger regional model of New Zealand-wide circulation at a grid size of $5 \times 5 \mathrm{~km}$. The high-resolution model was validated using tidal elevations obtained from a tide gauge at Tiritiri Matangi, located approximately $50 \mathrm{~km}$ northwest of the study site $\left(36.605^{\circ} \mathrm{S}, 174.888^{\circ} \mathrm{E}\right)$ (Supplement 1 ).

\subsubsection{Lagrangian particle tracking}

Using the open source Lagrangian particle tracking software OpenDrift v.1.0 (Dagestad et al. 2018), we simulated individual dispersal trajectories for particles (representing recently spawned larvae) released from 5 selected aquaculture sites throughout the FoT (COR, MAN, WP, WB1, WB2; Fig. 1). Sites were selected to represent areas at which mussel aquaculture occurs in the FoT. Two sites were within (COR) or close to the entrance (MAN) of sheltered harbours; 2 sites represented the large exposed blocks of mussel farms in the eastern FoT (WB1 and WB2), and one site represented the small mussel farms in the western FoT (WP). The OpenDrift particle trajectory model was coupled to the hydrodynamic model. A new OpenDrift submodel based on the already available 'PelagicEgg' 
module was developed specifically for mussel larvae ('Bivalvelarvae' model) and is available at https:// github.com/simonweppe/opendrift/blob/master/ opendrift/models/bivalvelarvae.py.

The model operated with an internal timestep of $15 \mathrm{~min}$. A horizontal diffusion coefficient of $0.1176 \mathrm{~m}^{2} \mathrm{~s}^{-1}$ was included based on the equations of Okubo \& Ebbesmeyer (1976) to account for subgrid-scale diffusion. A vertical diffusion constant of $0.01 \mathrm{~m}^{2} \mathrm{~s}^{-1}$ over a 15 min timestep was included to account for turbulence in the fluid environment (based on parameters previously used for bivalve larval dispersal in Lundquist et al. 2004). A total of 4.9 million particles were released between the months of December and June, when peak settlement occurred over the years 1995-2005 (Alfaro et al. 2001, Smith 2019). Release sites were selected to represent all general areas in which mussel aquaculture occurs. Particles were evenly released within polygons delineated by mussel farming operations (Fig. 1). As management and harvest practices are consistent within New Zealand (Jeffs et al. 1999) and therefore across the study area, the number of particles released from each site was scaled to the surface area occupied by each farm. Particles were released at a density of 10 particles $\mathrm{km}^{-2}$ of surface area of mussel farm at $2 \mathrm{~h}$ intervals to ensure particles were seeded across the tidal cycle. Full model parameters are presented in Table 1.

Particles were seeded at random depths within the water column between 1 and $10 \mathrm{~m}$ to simulate the depth of the dropper lines on which mussels are cultivated (Jeffs et al. 1999). No robust information exists

Table 1. Parameters used in biophysical modelling of Perna canaliculus in the Firth of Thames

\begin{tabular}{|ll|}
\hline Variable & Value \\
\hline Horizontal diffusivity & $0.1176 \mathrm{~m}^{2} \mathrm{~s}^{-1}$ \\
Vertical diffusivity & $0.01 \mathrm{~m}^{2} \mathrm{~s}^{-1}$ \\
Turbulent mixing timestep & $900 \mathrm{~s}^{-1}$ \\
Terminal fall velocity & $0.0025 \mathrm{~m} \mathrm{~s}^{-1}$ \\
Minimum settlement age & $3 \mathrm{wk}$ \\
Maximum settlement age & $5 \mathrm{wk}$ \\
Internal timestep & $15 \mathrm{~min}$ \\
External timestep & $6 \mathrm{~h}$ \\
Density of particles & $1 \mathrm{particle}$ per $500 \mathrm{~m}^{2}$ of aqua- \\
released per timestep & culture surface area \\
Particle release depth & Randomly between 1 and \\
& $10 \mathrm{~m}$ depth \\
Particle release timestep & Every 2 h during release \\
& months and years \\
Release months & December-April \\
Years modelled & $1995-2005$ \\
\hline
\end{tabular}

on whether these mussels exhibit active horizontal or vertical swimming behaviour, though New Zealand bivalve larvae have been observed to be well distributed throughout the water column in a large harbour (Lundquist \& Broekhuizen 2012). Particles were therefore given a terminal sinking velocity of 0.0025 $\mathrm{m} \mathrm{s}^{-1}$, which is at the lower range of settling velocities of larger bivalve larvae and may take into account some active settlement behaviour (Chia et al. 1984, Lundquist et al. 2009). Particles were released every $2 \mathrm{~h}$ for the full 7 mo settling period (Dec-June) every year from 1995-2005 and tracked for up to $5 \mathrm{wk}$. Age-dependent settlement was included in the model; if a particle encountered the seafloor or the coast (settlement habitat) between 3 and 5 wk after release (the settlement competency window) (Jeffs et al. 1999), it was deemed to have settled and remained at this location. Particles which did not encounter settlement habitat within this period were retired from the model as this is beyond the known pelagic larval duration of this species (Hayden 1995). Due to the unavailability of data regarding the survival of mussel larvae, we assumed that mortality was spatially and temporally uniform. Thus, we did not include potential variations in daily mortality rates, but rather report proportional larval transport from each site.

\subsubsection{Biophysical model analysis}

Analysis of the OpenDrift output 'netcdf' files was conducted in MATLAB R2018a (MathWorks). Kernel density estimations (KDEs) were calculated using the methods of Botev et al. (2010). KDEs represented the probability that a released particle would settle in a given location. A total KDE was calculated for all particles released from all sites in the model. As the total $\mathrm{KDE}$ was dominated by particles released from areas with high surface area (WB1 and WB2), individual KDEs for particles released from each site were also calculated. The total proportion of particles which encountered suitable settlement habitat relative to the total number of particles released from each site over the $11 \mathrm{yr}$ modelled period was also calculated.

\subsection{Trace elemental fingerprinting}

\subsubsection{Study sites}

A total of 8 sites within the FoT were selected for trace elemental fingerprinting (C1-C7, W1; Fig. 1). Four of these sites were selected as they were within 
areas used for longline aquaculture and therefore potential larval sources. These included 3 of the modelled release sites (C3, C5, and W1). One of these aquaculture locations was situated in the western FoT at Waimang Point (W1), 2 were situated within Coromandel Harbour (C5 and C6), and 1 was situated within the large mussel farm blocks at Wilson Bay (C3). The remaining sites were selected as preliminary hydrodynamic modelling indicated they were within distances over which larvae from these aquaculture sites were able to disperse. Additionally, due to significant and varied anthropogenic modification of the study area over the last $100 \mathrm{yr}$ (Hauraki Gulf Forum 2017), shell material produced at these sites is likely to differ in its trace elemental composition. Sites were generally between 2 and $5 \mathrm{~km}$ apart, although the largest distance between sites was $14.6 \mathrm{~km}$ (W1-C3) and the shortest was $1.5 \mathrm{~km}(\mathrm{C} 5-\mathrm{C} 6)$.

\subsubsection{Field sampling}

To determine natural variation in the trace elemental composition of mussels and establish reference trace elemental fingerprints within the study area, an in situ culturing technique was used (e.g. Becker et al. 2007, Kroll et al. 2018). Whilst previous studies have employed both moored and drifting in situ culturing methods to develop reference trace elemental fingerprints with differing results, it is difficult to establish which is more accurate (Kroll et al. 2018). We therefore elected to use a moored in situ culturing method for the development of reference trace elemental fingerprints. Macroalgae with juvenile mussels attached were harvested from the low intertidal zone at $\mathrm{M}$ ori Bay on the west coast of northern New Zealand $\left(36.837^{\circ} \mathrm{S}, 174.427^{\circ} \mathrm{E}\right)$. This site was selected due to consistent year-round supply of juveniles and spat. Mussels were transported to the School of Biological Sciences at The University of Auckland, where individuals between 2 and $8 \mathrm{~mm}$ shell height were removed from the macroalgae and placed into in situ culturing containers (ICCs). Although incorporation of elements into shell material may vary with age (Strasser et al. 2008), previous research has shown that these ontogenetic differences in trace elemental fingerprints are unlikely to mask spatial differences (Norrie et al. 2016). ICCs were constructed from $750 \mathrm{ml}$ food-grade, highdensity polyethylene jars with the lids and bases removed. Each end of the jar was covered with $500 \mu \mathrm{m}$ Nitex $^{\circledR}$ mesh. This mesh size allowed for flow of water carrying nutrients but prevented the escape of animals. At least 20 juveniles were placed into each ICC, however up to 30 were translocated if enough animals were collected.

At each site, artificial settlement substrates (SSs) were deployed in order to collect recent settlers at each site. Plastic mesh tuffy scrubbing pads (SOS Tuffy, Clorox) were used as they have been extensively employed in previous settlement studies (reviewed by South 2016). Settlement on these substrates is widely accepted to be a proxy for larval supply (South 2016). These SSs were deployed with ICCs to form an experimental unit. To create an experimental unit, one ICC was attached to a rope at a depth of $7 \mathrm{~m}$ with one SS approximately $10 \mathrm{~cm}$ above the ICC and one $10 \mathrm{~cm}$ below. At each site, 3 of these experimental units were deployed on each sampling event $\left(\mathrm{n}_{\mathrm{SS}}=3\right.$, $\mathrm{n}_{\mathrm{ICC}}=3$ site $^{-1}$ per sampling event). Experimental units were deployed for approximately $5 \mathrm{wk}$, although inclement weather events resulted in different deployment lengths on each sampling occasion (ranging from 29-55 d) and the loss of all equipment at some sites for some dates. All sampling occurred over the austral summer and autumn (Jan-May) in a single year (2018), as this is a period of high settlement in the study area (Smith 2019). After retrieval, animals were removed from each ICC, placed into plastic zip lock bags, and frozen at $-20^{\circ} \mathrm{C}$ until analysis. Each SS was placed into a zip lock bag in its entirety, as mussels are easier to remove from settlement substrate after freezing and thawing (Smith 2019).

\subsubsection{Sample preparation for trace elemental analysis}

Mussels from each ICC were defrosted and the shells were split open. One valve was randomly selected from each individual and any adhering particles were removed using stainless steel forceps. We inspected shells prior to translocation to ensure that shell material was a dark green. After recovery of ICCs, shell material with a distinct lighter green colour band following dark colourations was deemed to have been deposited in situ (Fig. 2a). The most recently formed portion of shell with a light green colour band along the axis of maximum growth was broken off and mounted onto microscope slides using double sided adhesive tape. If no distinct colour changes were observed, shells were not used for elemental analysis.

Settlers collected from 3 SSs at each site on each sampling occasion were analysed. In the laboratory, each SS was defrosted and all material was washed 

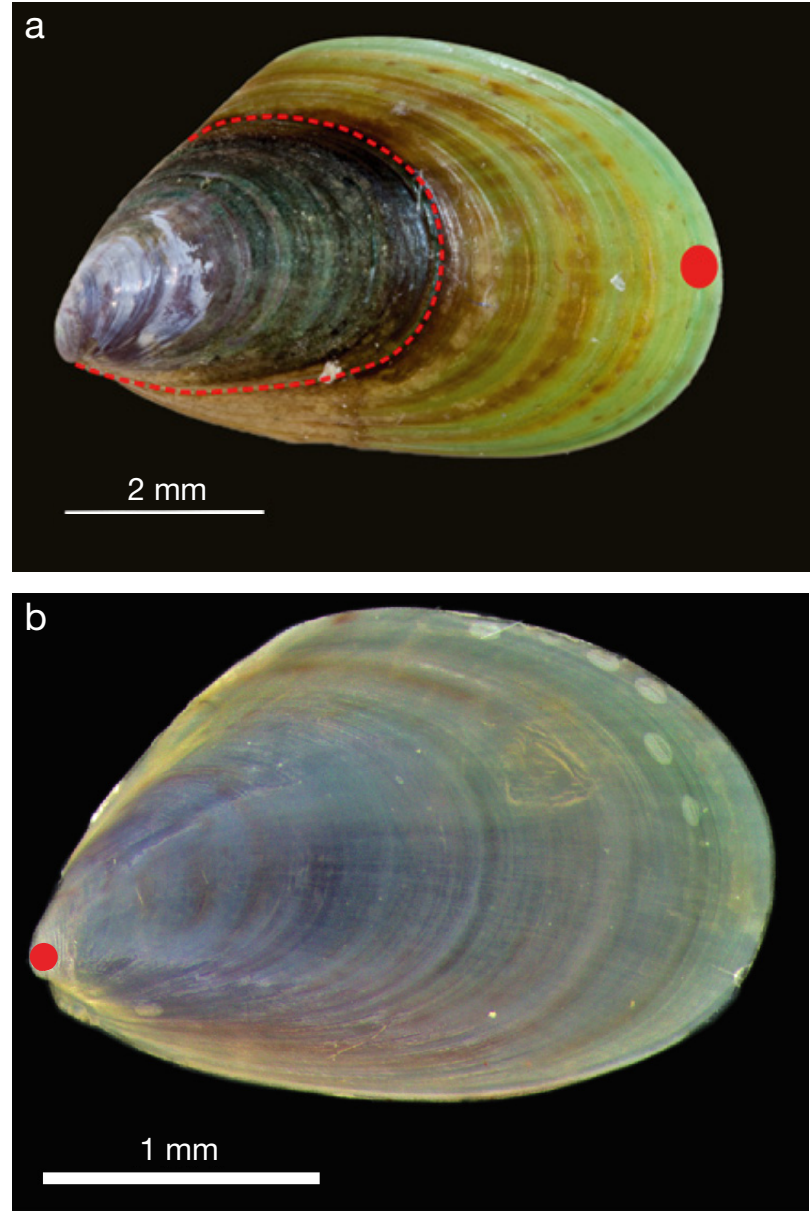

Fig. 2. Example of individual Perna canaliculus used for trace elemental fingerprinting. (a) Individual grown in an in situ culturing container to develop a reference elemental fingerprint. Dashed red line: separation between shell formed prior to translocation and that deposited in situ. (b) Recently settled individual from an artificial settlement substrate. Red dots: location of LA-ICP-MS analysis on each individual

with tap water through a $200 \mu \mathrm{m}$ sieve. All material washed off each SS was placed into deionised water (maintained at a resistivity of $<1 \mathrm{M} \Omega \mathrm{cm}$ ), and mussels were sorted from this material. Mussels from each SS were selected and fixed to a microscope slide with double sided adhesive tape.

\subsubsection{Trace element analysis}

To determine the trace elemental composition of shell material, laser ablation inductively coupled plasma mass spectrometry (LA-ICP-MS) was used. Elemental analyses were performed using a New Wave deep ultraviolet (193 nm) laser ablation system (Elemental
Scientific Industries) coupled to an Agilent 7700 ICPMS (Agilent Technologies). The laser operated with a spot size of $50 \mu \mathrm{m}$, a repetition rate of $5 \mathrm{~Hz}$, and a dwell time of $30 \mathrm{~s}$. Laser power was $45 \%$ and fluence was between 7 and $7.5 \mathrm{~J} \mathrm{~cm}^{-2}$. National Institute of Standards and Technology (NIST) 610 and 612 glass standards were analysed every 20 spots for standardisation, calculation of internal precision, and calibration purposes. For full laser operating parameters and detection limits, see Supplement 2 (Tables S2 \& S3).

All analyses were performed at the University of Auckland Plasma Mass Spectrometry Centre. Initially, 13 elements were monitored (Mn, Li, Co, Mg, B, Ca, Sr, $\mathrm{Zn}, \mathrm{Cu}, \mathrm{Ti}, \mathrm{Ni}, \mathrm{Ba}, \mathrm{Al})$. However, preliminary experiments revealed potential contamination from ICCs of $\mathrm{Li}, \mathrm{B}$, and $\mathrm{Cu}$ in shell cultured in these containers (Supplement 3), therefore these elements were excluded from further analyses. On reference shell material deposited in ICCs, one LA-ICP-MS spot was performed on the section of broken off shell approximately $200 \mu \mathrm{m}$ from the ventral margin of shells (Fig. 2a). This material represented the most recently formed shell. On naturally settled individuals collected on the SS, the prodissoconch was analysed (Fig. 2b), as this reflects shell material formed at the individual's natal location (Becker et al. 2007, Carson et al. 2011).

Data was processed using IOLITE trace elemental reduction software (Paton et al. 2011). Backgrounds were monitored for $30 \mathrm{~s}$ prior to each analysis. Data was then background-corrected by subtracting background average counts from the ablation counts. A pre-ablation procedure where the first $5 \mathrm{~s}$ of the ICP-MS signal was not included in the data was used to ensure that possible surface contamination or the periostracum was not included in the data (Marr et al. 2011, Norrie et al. 2016). To minimise the possibility of laser burn through to lower layers in the shell (Strasser et al. 2007), only the next $10 \mathrm{~s}$ of the laser dwell time was included in analyses. Data was then standardised using the most recent published NIST610 and NIST612 values (Jochum et al. 2005). All data was standardised to a trace element:calcium ratio (TE:Ca) in $\mu \mathrm{mol}$ of each TE to mol of Ca.

\subsubsection{Statistical analyses}

A discriminant function analysis (DFA) was performed on the TE:Ca ratios of shell material deposited in the ICCs. This allowed the examination of spatial variation in trace elemental fingerprints and development of site-specific reference signals. Due to differing covariances, a quadratic DFA (QDFA) was performed. 
Elements were included stepwise into this QDFA to determine the optimal suite of elements for classification of shell material to its formation location (Dunphy et al. 2015, Norrie et al. 2016). QDFA statistical analyses were performed in JMP v.13 (SAS Institute). Due to the loss of sampling equipment at some sites through weather events over the study period, a QDFA was performed in which all samples collected from each site were binned together, regardless of the date collected. This allowed the development of mean trace elemental fingerprints for each site.

To predict natal origins, the discriminant function trained with the TE:Ca ratios of shell material deposited in ICCs was then used to assign the shell material at the umbo of each shell to a predicted formation location. As the loss of sampling equipment resulted in differing deployment durations for SSs, the number of settlers predicted to have originated from each site was standardised to a per day settlement rate. Receiver operating characteristic (ROC) curves were generated for each site to estimate the diagnostic ability of the QDFA. These ROC curves compared the true positive rate against the false positive rate. Posterior probabilities of each individual being correctly assigned to its formation location relative to other sites were also calculated in order to provide estimates of the confidence of the estimates.

\section{RESULTS}

\subsection{Biophysical modelling}

\subsubsection{Lagrangian KDEs}

The total KDE of all particles released from all sites over the $11 \mathrm{yr}$ modelled period (Fig. 3) indicates the area with the highest probability of receiving settlers was located on the eastern FoT to the north and south of the WB1 and WB2 release sites. Particles are likely to settle on the east and west coasts of the FoT (but not the south) with a higher likelihood of coastal settlement on the eastern FoT than the western FoT. The KDE indi- cated that benthic settlement is possible throughout the FoT, although it is concentrated in the east. The model also suggested a low probability of larvae being transported from the FoT to the greater Hauraki Gulf, particularly the area north of Coromandel Harbour and between Ponui Island and the mainland. This total KDE is dominated by particles released at areas with a high surface area from which more particles were released, therefore individual KDEs were generated for particles released from each site (Fig. 4).

The site-specific KDEs (Fig. 4) indicated that particles released from sites which were more sheltered

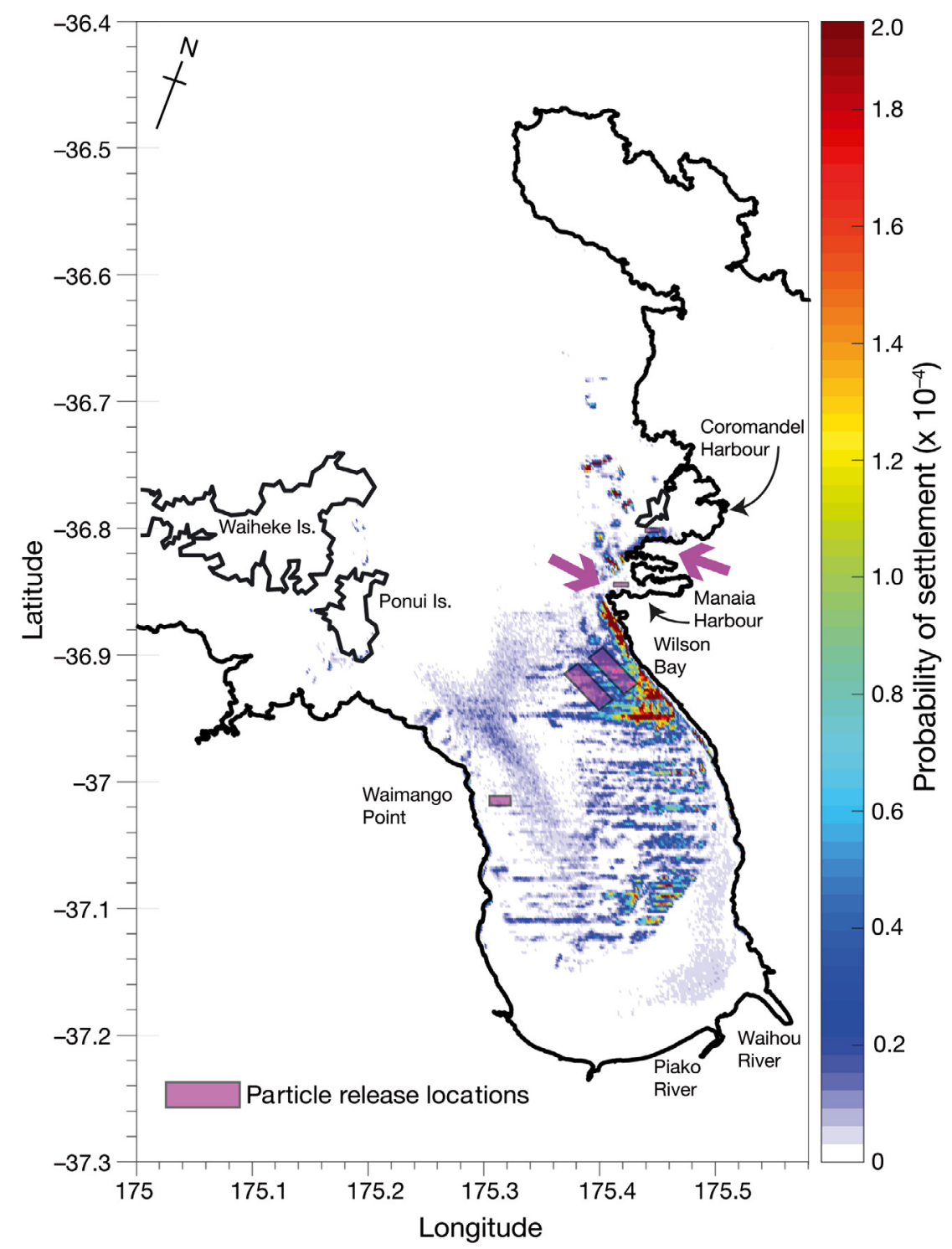

Fig. 3. Kernel density estimates of all settled particles from all Perna canaliculus model release sites over all release dates in the Firth of Thames. Colour scale: probability that a particle will settle at a given location relative to the total number of parties released. Arrows: location of particle release locations that are difficult to see due to their size 
settled over a smaller area than those released from more exposed sites. This can be seen by particles released from COR exhibiting the highest probability of settlement in the relatively small area close to the mouth of Coromandel Harbour (Fig. 4a). Particles released from MAN also exhibited a high likelihood of settlement over a relatively small area close to their release site (Fig. 4b). A number of these particles, however, settled throughout the FoT, particularly in the area north of Coromandel Harbour.

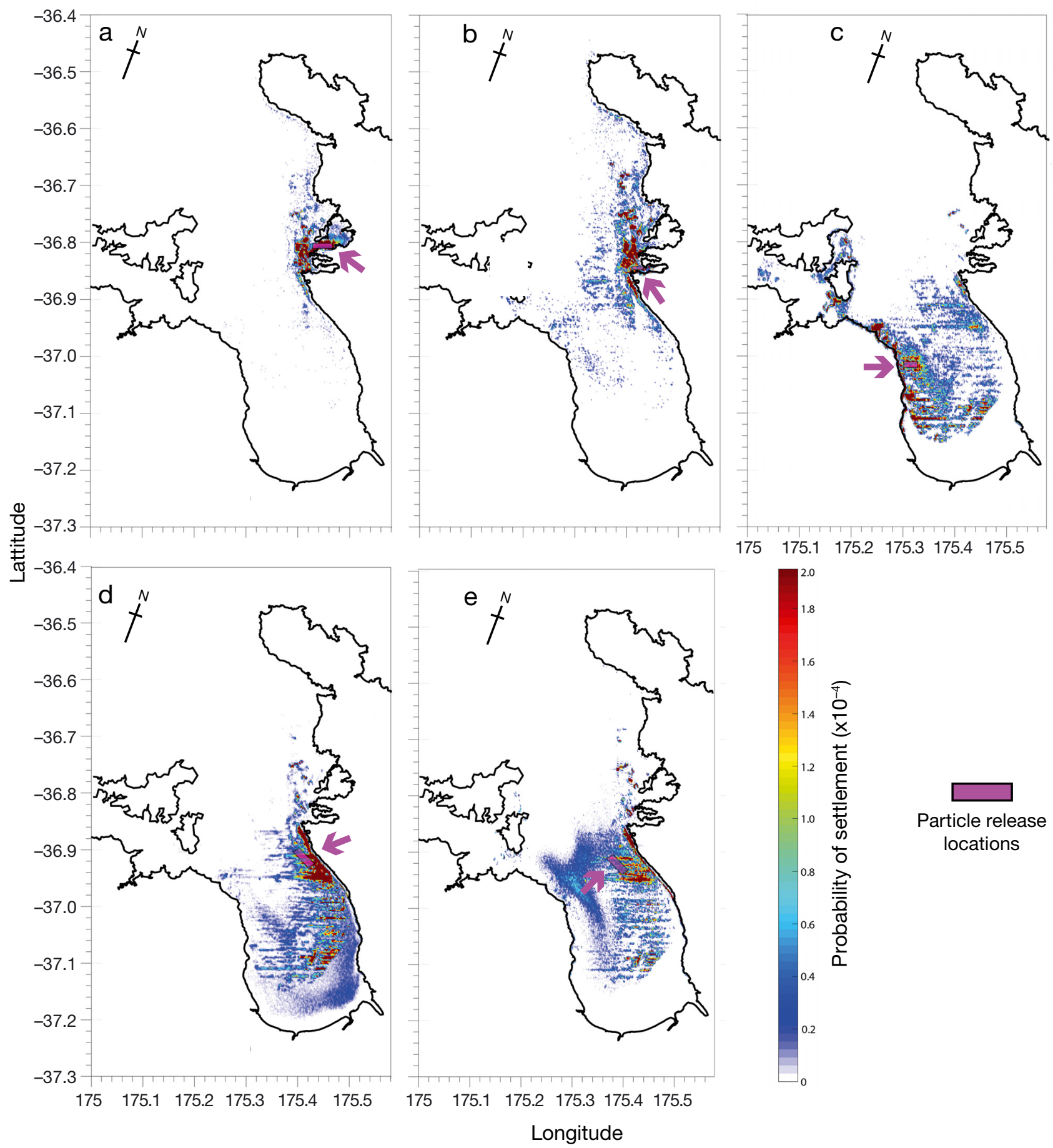

Fig. 4. Site-specific kernel density estimates of settled Perna canaliculus particles released from (a) COR, (b) MAN, (c) WP, (d) WB1, and (e) WB2. All settled particles released over the December-June release window during the entire 11 yr period are shown. Colour scale: portion of particles that settled at each location relative to the total number of particles released from that site. Arrows: locations of particle release locations 
The 3 more exposed sites (WP, WB1, and WB2) had predicted settlement over wide areas throughout the FoT. Particles from WP (Fig. 4c) exhibited high settlement probabilities to the south and south east of the release site, including on the western coast of the FoT. A number of particles also settled on the eastern side of the FoT, particularly in the area south of Manaia Harbour. Particles released from the WB1 and WB2 sites (Fig. 4d,e) also settled throughout the FoT. The settlement patterns of particles released from these sites was broadly similar, with areas of high settlement probability located close to their release site as well as along the eastern coast of the FoT as far south as the town of Thames. Differences in in the settlement probabilities between the 2 sites were most evident in the south and northwest of the FoT. Particles released from WB1 were likely to settle in the southern FoT close to the Waihou River (Fig. 4d), whilst particles released from WB2 had a higher probability of settling in the north western FoT (Fig. 4e).

\subsubsection{Spatial differences in the proportion of settled particles}

Only $30 \%$ of the 4.9 million particles released between December and April across the years 1995-2005 encountered suitable settlement habitat (the coast or seafloor) during the settlement competency window. The remaining $70 \%$ of particles which did not settle were retired from the model. Differential settlement rates were observed between sites (Fig. 5). Highest settlement rates were predicted for particles released from the relatively sheltered sites COR (77\% of particles settled) and MAN (53\% settled). Conversely, the more exposed sites had a much lower proportion of settled particles which decreased as their distance from the coast increased: $35 \%$ of particles released from WP settled, $33 \%$ of those released from WB1 settled, and only $23 \%$ of particles released from WB2 encountered suitable settlement habitat during the settlement competency period.

\subsection{Trace elemental fingerprinting}

\subsubsection{Spatial variation in trace elemental fingerprints}

Overall, the QDFA on reference shells correctly classified $72 \%$ of individuals to their growth location using 7 TE:Ca ratios (Mn:Ca, Co:Ca, Ba:Ca, Ti:Ca,

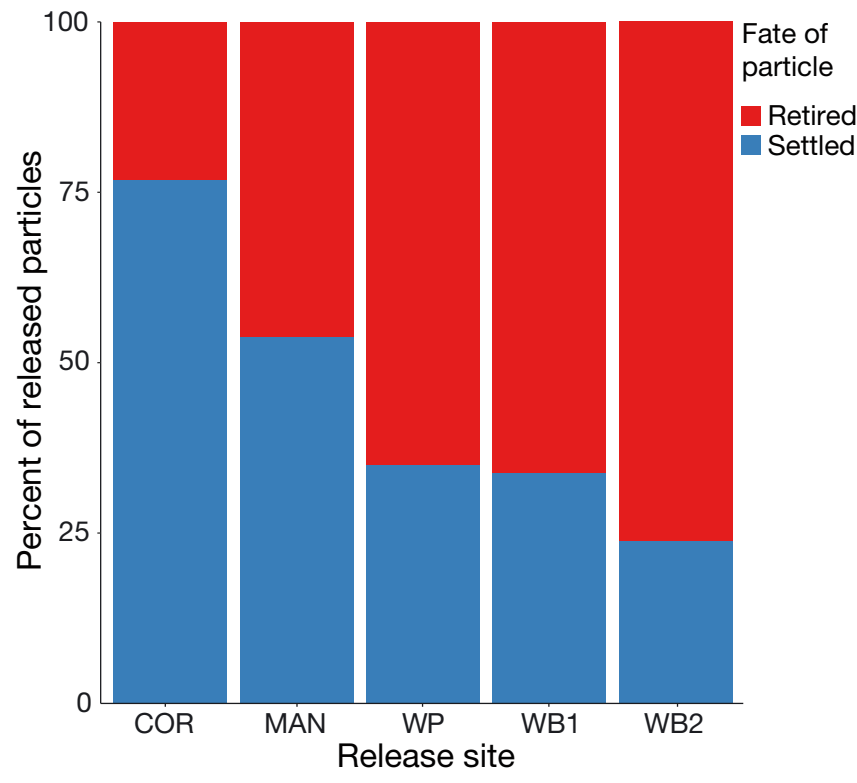

Fig. 5. Percent of Perna canaliculus particles released from each site which encounter suitable settlement habitat (defined as the seafloor or coast) during the settlement competency window 3-5 wk after release. Retired: the particle did not encounter suitable settlement substrate within the settlement competency window and was therefore removed from the model

$\mathrm{Mg}: \mathrm{Ca}, \mathrm{Sr}: \mathrm{Ca}, \mathrm{Zn}: \mathrm{Ca}$ ) (Table 2). This is highlighted by the plot of the canonical scores from the QDFA (Fig. 6) indicating differences between elemental fingerprints of shell grown at different sites. However, individual site-level classification success was variable. High levels of classification success were observed at C2 (89\%), C3 (100\%), C5 (90\%), and W1 $(92 \%)$, indicating unique trace elemental fingerprints in shells deposited at these sites. Classification rates of shell material deposited at C1 was moderate, with $71 \%$ of individuals correctly classified. Approximately half of individuals grown at C4 (53\%), C6 $(55 \%)$, and C7 (52\%) were correctly classified. The variability observed in the trace elemental fingerprints of shell material at $\mathrm{C} 4, \mathrm{C} 6$, and $\mathrm{C} 7$ shows that these sites are more difficult to differentiate based on their trace elemental fingerprint. The ROC curves were high for all sites (0.89-0.99), indicating the sensitivity of the QDFA was high (Table 2). Despite the relatively short distance between C5 and C6 $(1.2 \mathrm{~km})$, there were large differences in the trace elemental fingerprint of shell material deposited at these sites. Overall, $90 \%$ of individuals from C5 were correctly classified to their growth site. Classification success at C6, however, was only $55 \%$ with the majority of misclassified individuals attributed to $\mathrm{C} 1$, which was located furthest from $\mathrm{C} 6$ at approximately $16 \mathrm{~km}$ away. 
Table 2. Classification success rates of Perna canaliculus shell material deposited in the in situ culturing containers between January and May 2018. All individuals were grouped by site regardless of the dates on which they were collected. Bold values indicate correct classification to growth site. ROC: receiver operating characteristic

\begin{tabular}{|c|c|c|c|c|c|c|c|c|c|c|c|c|}
\hline \multirow{2}{*}{$\begin{array}{l}\text { Collection } \\
\text { location }\end{array}$} & \multirow{2}{*}{$\overline{\mathrm{C} 1}$} & \multicolumn{6}{|c|}{ Predicted collection location } & \multirow{2}{*}{$\overline{\mathrm{W} 1}$} & \multirow[t]{2}{*}{ No. collected } & \multirow[t]{2}{*}{ No. correct } & \multirow[t]{2}{*}{$\%$ Correctly classified } & \multirow[t]{2}{*}{ ROC curve } \\
\hline & & $\mathrm{C} 2$ & $\mathrm{C} 3$ & $\mathrm{C} 4$ & C5 & $\mathrm{C} 6$ & $\mathrm{C} 7$ & & & & & \\
\hline C1 & 89 & 8 & 0 & 2 & 2 & 11 & 6 & 7 & 125 & 89 & 71.2 & 0.92 \\
\hline $\mathrm{C} 2$ & 0 & 25 & 0 & 0 & 0 & 1 & 1 & 1 & 28 & 25 & 89.2 & 0.97 \\
\hline $\mathrm{C} 3$ & 0 & 0 & 13 & 0 & 0 & 0 & 0 & 0 & 13 & 13 & 100 & 0.99 \\
\hline $\mathrm{C} 4$ & 7 & 5 & 0 & 29 & 2 & 3 & 4 & 4 & 54 & 29 & 53.7 & 0.93 \\
\hline $\mathrm{C} 5$ & 1 & 0 & 0 & 0 & 19 & 1 & 0 & 0 & 21 & 19 & 90.4 & 0.99 \\
\hline $\mathrm{C} 6$ & 3 & 7 & 4 & 2 & 3 & 28 & 1 & 3 & 51 & 28 & 54.9 & 0.89 \\
\hline $\mathrm{C} 7$ & 2 & 0 & 0 & 0 & 4 & 7 & 23 & 8 & 44 & 23 & 52.2 & 0.94 \\
\hline W1 & 1 & 1 & 0 & 0 & 1 & 2 & 0 & 66 & 71 & 66 & 92.9 & 0.97 \\
\hline No. predicted & 103 & 46 & 17 & 33 & 31 & 53 & 35 & 89 & 407 & 292 & 71.74 & \\
\hline
\end{tabular}

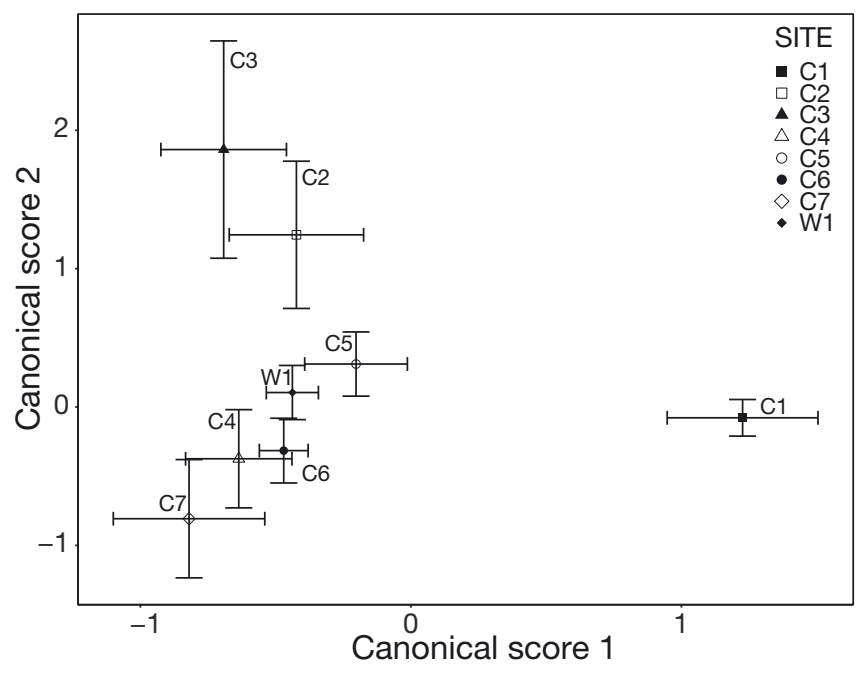

Fig. 6. Mean $( \pm$ SEM) canonical scores from the quadratic discriminant function analysis examining trace element to Ca ratios in the shell material of all Perna canaliculus individuals collected from monitored sites between January and May 2018

\subsubsection{Natal locations of recent settlers}

The predicted larval origins of recent settlers collected at each of the sites monitored (Fig. 7, Table 3) suggested that the larval pool in the FoT is well mixed. Settlers collected at each site were a combination of larvae produced throughout the study region. A minimum of 5 and a maximum of 7 potential natal locations were predicted for settlers at each site. No settlers at any of the sites collected over the study period of January-May 2018 were predicted to have originated at C3. The confidence of the model in assigning individuals to their natal location was high, as shown by the mean posterior probabilities of correct assignment to each group ranging from $0.73-0.83$
(Table 3) in agreement with the overall classification success rates of reference shell material (Table 2).

Although overall the larval pool was well mixed, some sites acted as larval sources and sinks relative to others. The most important larval source from the perspective of the highest number of larvae produced was C7. Of the individuals which settled at monitored sites, $30 \%$ were predicted to have originated from this location (1.63 settlers $\mathrm{d}^{-1}$ ) (Table 3 ). The high contributions made by $\mathrm{C} 7$ were primarily driven by the high number of settled larvae originating from C7 at W1, which had the highest settlement rates of all sites monitored with 2.66 mussels $\mathrm{d}^{-1}$ settling at this location (Table 3). A large proportion of larvae which settled at C1 (48\%; 0.28 settlers $\left.\mathrm{d}^{-1}\right)$ and C2 (46\%; 0.25 settlers $\mathrm{d}^{-1}$ ) were also predicted to have originated from this location. A large proportion of larvae which settled throughout the study region were also predicted by the QDFA to have originated at W1 in the western FoT (0.95 settlers $d^{-1}$ ) (Table 3). Self-recruitment was generally low throughout the FoT with C7 (20\% self-recruitment), W1 (14\%), and C2 (15\%) exhibiting the highest levels of the sites monitored. No settlers throughout the FoT were predicted to have originated at C3 despite the moderate settlement at this location. Only small numbers of larvae were predicted to have originated at both $\mathrm{C} 2$ and $\mathrm{C} 5$; although settlement at C5 was low, a moderate number of larvae settled at C2. These 3 sites can be considered larval sinks as few larvae from throughout the FoT were predicted to have originated at these locations.

\section{DISCUSSION}

This study set out to answer the following questions. (1) What is the potential for dispersal of Perna 

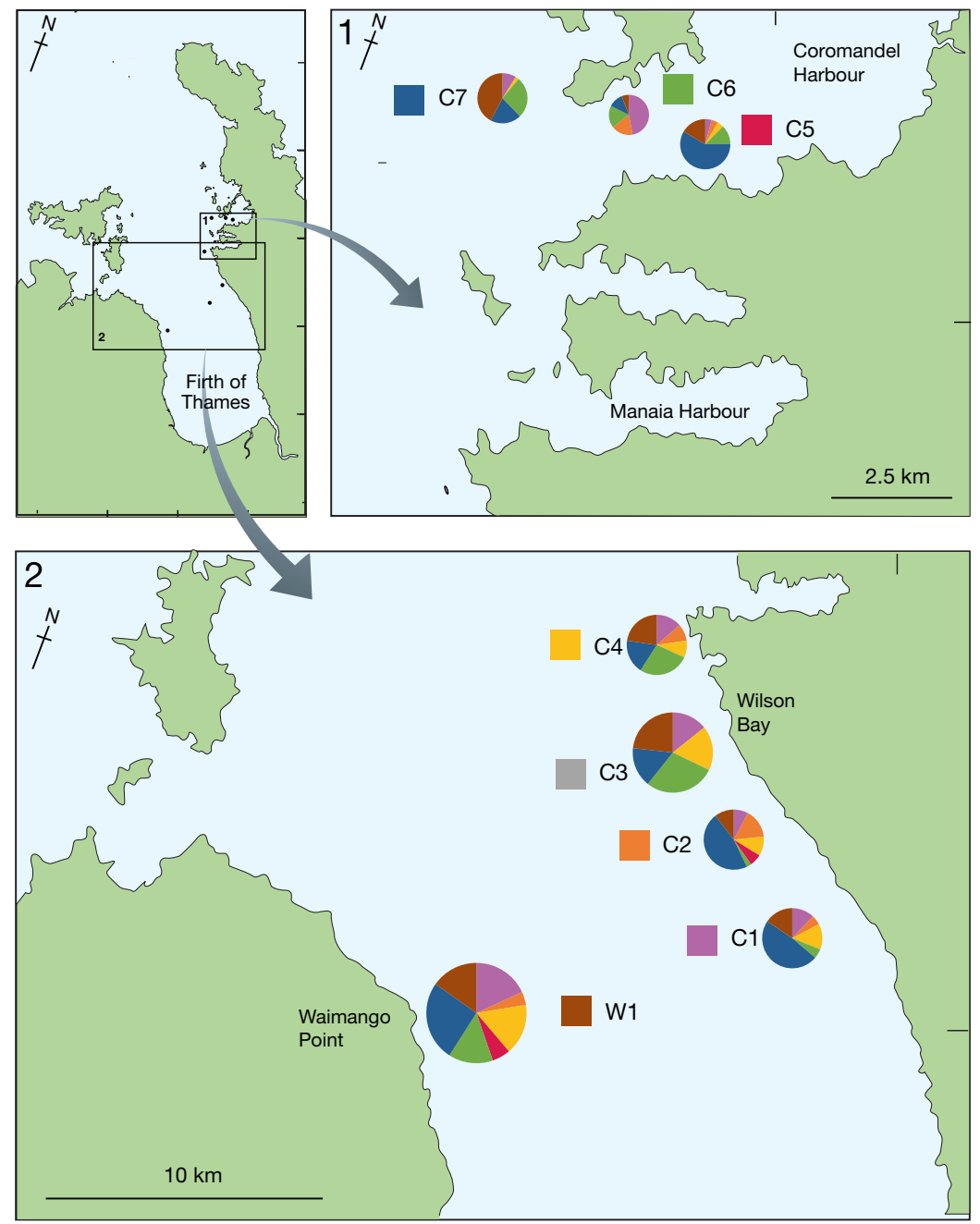

Fig. 7. Proportional natal locations of Perna canaliculus settling at monitored locations throughout the Firth of Thames as predicted by the quadratic discriminant function analysis trained using shell material deposited in situ at these locations. Coloured square adjacent to the site names (W1-C7): colour codes of settlers originating from these sites. Note the size of circle indicates the number of settlers at each site standardised per day (Table 3)

dicted by each technique. These differences highlight the importance of incorporating multiple tracking techniques for a holistic understanding of larval dispersal patterns. Together, our results provide the first evidence, to our knowledge, that larvae produced in aquaculture can assist in the restoration of degraded wild bivalve populations through a larval subsidy).

\subsection{What is the potential for dispersal of $\boldsymbol{P}$. canaliculus from aquaculture locations throughout the FoT?}

Both biophysical modelling and trace elemental fingerprinting indicated the Waimang Point mussel farms (WP, W1) were likely to be a source of mussel larvae which settle throughout the study area. In addition to contributing larvae to several sites, high settlement rates at this location also indicate that Waimang Point receives settlers from several locations. In a restoration context, the fact that this location may both receive and contribute larvae highlights the potential importance of this site in regional population dynamics. Restoration of benthic mussel beds at this site may provide habitat for larvae produced in other areas of the FoT as well as contribute larvae to other populations in the area.

Trace elemental fingerprinting predicted that the area to the north of Coromandel Harbour (C7) is an impor-

canaliculus from aquaculture locations throughout the FoT? (2) How do larval dispersal patterns generated by biophysical modelling and trace elemental fingerprinting differ? (3) What are the overall implications of any larval spill-over for restoration and aquaculture? The results of both the trace elemental fingerprinting study and the biophysical modelling indicated that there is potential for larval spill-over from aquaculture to areas throughout the FoT. The larval pool in the FoT is likely to be well mixed, with larvae from all sites potentially contributing settlers to, and receiving settlers from, other locations. Although the results of both approaches showed similar broadscale results, different dispersal pathways were pretant larval source for settlers throughout the study area despite no known populations existing at this location. The biophysical model predicted settlement at this location was likely to be high, particularly for larvae released from Manaia and Coromandel Harbours (MAN and COR). One such explanation for this result may be that early stage larvae dispersing past this location incorporate elemental fingerprints from this site, although this is unlikely as hydrodynamic modelling indicated larvae in this area are retained close to their natal location for several days. Alternatively, these results present the possibility that a population exists at this location supported by aquaculture which may then in turn act as a source of larvae 
Table 3. Predicted formation locations of Perna canaliculus shell material at the prodissoconch of individuals which settled at monitored sites in the Firth of Thames between January and May 2018. As weather events resulted in non-standard deployment times for settlement substrates, standardised settlement per day was calculated. Settler contribution rate was calculated as the number of settlers per day of sampling which were predicted to have originated at each site

\begin{tabular}{|c|c|c|c|c|c|c|c|c|c|c|c|}
\hline \multirow{2}{*}{$\begin{array}{l}\text { Collection } \\
\text { location }\end{array}$} & \multirow[b]{2}{*}{$\mathrm{C} 1$} & \multirow[b]{2}{*}{$\mathrm{C} 2$} & \multicolumn{6}{|c|}{ - Predicted natal location } & \multirow{2}{*}{$\begin{array}{c}\text { Total } \\
\text { no. } \\
\text { settled }\end{array}$} & \multirow{2}{*}{$\begin{array}{l}\text { No. of days settlement } \\
\text { substrate deployed } \\
\text { (no. of deployments) }\end{array}$} & \multirow{2}{*}{$\begin{array}{l}\text { Settlement } \\
\text { rate } \\
\left(\text { mussels d }^{-1}\right)\end{array}$} \\
\hline & & & C3 & $\mathrm{C} 4$ & C5 & C6 & $\mathrm{C} 7$ & W1 & & & \\
\hline C1 & 7 & 3 & 0 & 8 & 0 & 3 & 28 & 9 & 58 & $98(2)$ & 0.59 \\
\hline $\mathrm{C} 2$ & 6 & 12 & 0 & 8 & 5 & 2 & 36 & 8 & 77 & 139 (3) & 0.55 \\
\hline C3 & 8 & 0 & 0 & 10 & 0 & 16 & 9 & 13 & 56 & $84(2)$ & 0.67 \\
\hline $\mathrm{C} 4$ & 3 & 2 & 0 & 2 & 0 & 6 & 4 & 5 & 22 & $98(2)$ & 0.22 \\
\hline C5 & 1 & 1 & 0 & 1 & 0 & 3 & 14 & 4 & 24 & $84(2)$ & 0.29 \\
\hline C6 & 8 & 3 & 0 & 0 & 0 & 3 & 2 & 1 & 17 & 139 (3) & 0.12 \\
\hline $\mathrm{C} 7$ & 4 & 0 & 0 & 1 & 0 & 12 & 9 & 19 & 45 & 139 (3) & 0.32 \\
\hline W1 & 43 & 10 & 0 & 39 & 14 & 34 & 61 & 36 & 237 & $89(2)$ & 2.66 \\
\hline $\begin{array}{l}\text { Total no. predicted } \\
\text { natal origin }\end{array}$ & 80 & 31 & 0 & 69 & 19 & 79 & 163 & 95 & 536 & & 0.6775 \\
\hline $\begin{array}{l}\text { Settler contribution } \\
\text { rate (mussels d }{ }^{-1} \text { ) }\end{array}$ & 0.82 & 0.28 & 0 & 0.74 & 0.2 & 0.82 & 1.63 & 0.95 & & & \\
\hline $\begin{array}{l}\text { Mean posterior prob- } \\
\text { ability }( \pm \text { SEM })\end{array}$ & $\begin{array}{c}0.8 \\
( \pm 0.02)\end{array}$ & $\begin{array}{c}0.73 \\
( \pm 0.03)\end{array}$ & - & $\begin{array}{c}0.77 \\
( \pm 0.02)\end{array}$ & $\begin{array}{c}0.8 \\
( \pm 0.05)\end{array}$ & $\begin{array}{c}0.77 \\
( \pm 0.02)\end{array}$ & $\begin{array}{c}0.83 \\
( \pm 0.01)\end{array}$ & $\begin{array}{c}0.82 \\
( \pm 0.01)\end{array}$ & & & \\
\hline
\end{tabular}

for other sites in the FoT. This demonstrates the power of integrating the results of the 2 methods. The possibility of this stepping stone dispersal (Kimura \& Weisss 1964, Palumbi 2003) highlights the need to consider system-wide connectivity into management actions based on source-sink dynamics (Kininmonth et al. 2011). Future surveys of potential mussel populations in the FoT should investigate this location to determine the presence of a population at this location which may supply larvae throughout the study area.

There are several larval sinks in the FoT study area. The area with the highest probability of settlement as predicted by the biophysical model was located to the south of Manaia Harbour, with larvae from each release site capable of settling at this location. Trace elemental fingerprinting also demonstrated that larvae settling in this area $(\mathrm{C} 1, \mathrm{C} 2)$ likely originated from multiple sources. This finding is important as the area is known to support one of the few extant populations of mussels in the FoT (A. Jeffs, University of Auckland, pers. comm.), suggesting that aquaculture may already be supporting this population. The biophysical model also predicted that the area to the south of the Wilson Bay mussel farms would have high rates of settlement. Although this location currently supports no known populations of mussels, it is anecdotally known by local mussel farmers to be an area of high spat settlement (Smith 2019). Moderate settlement was also observed on artificial SSs in this area $(\mathrm{C} 1, \mathrm{C} 2)$.
The similarity between the 2 methods of estimating larval dispersal shows that decisions on management in the study area based on this data can be made with a high degree of confidence and highlights the advantages of employing multiple techniques. The restoration of settlement habitat at these sink locations may allow the recovery of benthic mussel populations in this area due to high larval supply. Although adults are able to survive in this area (McLeod et al. 2012), it is important to consider factors which may prevent the survival of larvae or juveniles both during and after dispersal (Brandt et al. 2008, Pineda et al. 2010, Shima et al. 2015).

\subsection{How do the 2 methods of estimating larval dispersal differ?}

Although the overall pattern of a well-mixed larval pool in the FoT was demonstrated by both methods of tracking larvae, several differences in the pathways of dispersal were observed. These differences highlight the need to integrate multiple techniques of estimating larval dispersal and population connectivity to obtain a clearer picture of dispersal patterns (Ashford et al. 2010, Nolasco et al. 2018). The primary difference was the lack of settlers attributed to the large mussel farm blocks off Wilson Bay (WB1, WB2, C3) by trace elemental fingerprinting despite the prediction of the biophysical model that settlers 
from this location would dominate settlement patterns throughout the study area. The biophysical model also predicted that larvae produced within Coromandel Harbour (COR, C5, C6) would be retained in this area, although this was not shown to be the case in by trace elemental fingerprinting techniques. Several possible explanations exist for the differences between the 2 methods of tracking the dispersal of larvae in the FoT.

It is likely that the variation in temporal scales over which the 2 studies were conducted was responsible for the differences observed. While the biophysical model considered circulation patterns over a $10 \mathrm{yr}$ period, trace elemental fingerprinting only examined settlement patterns over a single spawning season. It is unlikely that dispersal patterns within a single year will fit with the $10 \mathrm{yr}$ mean, as inter-annual variation in potential dispersal distances exists (Norrie 2019). This suggests that an extended sampling period should be undertaken to determine if long-term trends observed through different techniques agree. In addition to possible variations in circulation, environmental conditions in areas of predicted high settlement may not have been suitable for the survival and settlement of larvae. The study area experienced heat wave conditions over the period in which field sampling was conducted (Jan-May 2018) (Herring et al. 2019), with reports of high mortality of mussels in aquaculture operations. This may have reduced both larval production at some locations as well as reduced the survival of larvae.

Additionally, there was variation in settlement rates predicted by the biophysical model between sites. These differences were driven by the rate at which larvae encountered potential settlement habitat within the time period in which settlement is possible. These results show that sites which produce the highest numbers of larvae may not necessarily contribute the highest numbers of settlers to populations. These differences in the rates at which larvae encounter settlement habitat have the potential to interact with direct stresses placed on an individual as it disperses, such as predation, as well as indirect dispersal stresses which may reduce post-settlement survival (Nanninga \& Berumen 2014). Differences between the results of biophysical modelling and trace elemental fingerprinting highlight the need to consider realised dispersal and include empirical data into predictions of larval dispersal (Pineda et al. 2007). The similarities in overall patterns between the 2 methods employed in the current study highlight the utility of using computer-based simulations to guide the application of empirical validation experiments. These empirical experiments may then provide feedback towards validation and parameterisation of future models.

\subsection{What are the implications overall for restoration and aquaculture?}

The overall finding of larval spill-over from aquaculture has important consequences for the restoration and recovery of depleted bivalve populations. To our knowledge, this is the first study which demonstrates that bivalve aquaculture in coastal waters has the potential to provide a larval subsidy to relict and restored bivalve reefs and therefore assist with their recovery. This research shows that if bivalve aquaculture is conducted in an area with degraded bivalve populations, spill-over from these locations should be explicitly considered in restoration programmes. This research also shows that a network approach should be taken to restoration which includes connectivity between sites.

If larval spill-over from aquaculture to natural populations results in the recovery of degraded populations or assists with restoration efforts, connectivity to these locations should be maximised. This highlights the potential benefits of a network approach to restoration. The need for network approaches in marine reserve design is well known (e.g. Almany et al. 2007, Gaines et al. 2010, Green et al. 2015, Puckett \& Eggleston 2016, Coleman et al. 2017), and these approaches should be translated to the design of restoration programmes. Where larval spill-over is desirable, additional bivalve aquaculture locations should be carefully planned in the context of the system in which this culturing takes place to ensure that larval spill-over to natural populations is enhanced. New restoration efforts should also be considered in the context of new or existing bivalve aquaculture to determine locations at which effort should be applied in order to maximise the chances of success (Arnold et al. 2017). The inclusion of aquaculture populations may simplify these network approaches, as many aquaculture populations are restocked after harvest resulting in relatively stable populations without the need to receive settlers.

It is also important to consider the possibility that larval export from aquaculture may negatively affect local populations of bivalves. The escape of finfish from farming operations has been shown to have potentially deleterious consequences on wild populations through the reduction of genetic diversity (Jørstad et al. 2008, Morris et al. 2008, Jensen et al. 
2010). In bivalves, genetic introgression to wild stocks has also been demonstrated which may result in reduced fitness in the wild population (Apte et al. 2003). In cases where natural populations of a bivalve species exist, strategies which minimise potential larval export from aquaculture should be implemented. Potential strategies may include careful placement of aquaculture where settlement of larvae is unlikely, or the implementation of hatchery techniques such as spawning triploid bivalves with lower reproductive fitness (e.g. Honkoop 2003, Jouaux et al. 2010). In the case of the FoT, however, no large natural populations exist, making negative consequences less likely at present.

\subsection{Future directions}

This study has provided important insight into larval dispersal patterns from aquaculture and their interactions with restoration. However, to understand the ecological consequences of this dispersal it is essential that the survival to reproduction is quantified (Pineda et al. 2007, Nanninga \& Berumen 2014). Several stressors may prevent the establishment of mussel reefs despite high larval supply (Burgess et al. 2012). In addition to spatio-temporal variation in mortality (White et al. 2014, Pineda \& Reyns 2018), physiological stresses placed on an individual during dispersal, or post-settlement stresses may result in decreased fitness or lower reproductive output (Baker \& Rao 2004, Burgess \& Marshall 2011, Shima et al. 2015). Quantifying these stressors is essential for the selection and further assessment of viability of restoration sites, as larval supply and settlement will not result in a sustainable population if settlers do not survive. It is also important to quantify larval production in order to more accurately parameterise biophysical models and reconcile differences between modelled and empirically determined dispersal. For example, to better parameterise models, sites likely to receive high settlement as determined by modelling and empirical methods should now be monitored over long time scales in order to better understand inter- and intra-annual variation in larval production over the spatial extent of this study. Additionally, some locations are likely to result in lower larval output due to differences in the size structure of the population and age-dependent fecundity (Ren \& Ross 2005). This is particularly important in an aquaculture setting where harvests occur at a relatively small size, which may reduce larval production relative to wild populations.
Understanding the consequences of varying dispersal distances is also important in the context of climate change. Changing ocean conditions such as salinity and temperature may result in changes in hydrodynamic flows on a number of scales (Wu et al. 2012, Sen Gupta et al. 2015). As these changes in hydrodynamic flows will directly affect the potential dispersal of larvae, it is important that changes in realised connectivity are considered (Coleman et al. 2011, 2017). Modelling exercises, for example, have shown that while oceanic circulation changes may affect larval transport, faster development and therefore earlier settlement (related to temperature) could override the effects of these changed transport pathways (Cetina-Heredia et al. 2015) or vice versa. It is also important to consider that faster development of larvae in warmer waters will only occur if the supply of nutrients is high enough to support this development; however, the distribution of plankton is also likely to change, which may decrease larval growth rates and even possibly increase mortality rates (Munday et al. 2009, Andrello et al. 2015). Finally, the possibility of employing methods such as those used by Nolasco et al. (2018), which explicitly incorporate the results of biophysical models and trace elemental fingerprinting into a single statistical framework, could prove very powerful.

Acknowledgements. C.N. was supported by a UoA doctoral scholarship. Funding for fieldwork and laser analyses were provided by NIWA Coasts and Oceans core funding (COME1903). The hydrodynamic model was developed by MetOcean Solutions. M.R. was partially supported by the Moana Project (www.moanaproject.org), funded by the New Zealand Ministry of Business Innovation and Employment, contract number METO1801. Stuart Morrow from the UoA mass spectrometry centre aided with elemental analyses. Alex Vincent aided with figures. Jessica Bailey assisted in the laboratory. Fieldwork assistance was provided by Scott Edhouse, David Bremner, Peter Schlegel, Esther Stuck, Peter Browne, Errol Murray, and Jenny Hillman. Alan Bartrom of Gulf Mussels provided logistical support. Thanks to the Miller lab at OSU for their input on a draft of the manuscript. We also thank 2 anonymous reviewers and the editor for their constructive feedback which greatly improved previous versions of the manuscript.

\section{LITERATURE CITED}

Alfaro AC, Jeffs AG (2002) Small-scale mussel settlement patterns within morphologically distinct substrata at Ninety Mile Beach, northern New Zealand. Malacologia 44:1-15

Alfaro AC, Jeffs AG, Hooker SH (2001) Reproductive behavior of the green-lipped mussel, Perna canaliculus, in northern New Zealand. Bull Mar Sci 69:1095-1108 
Alfaro AC, Jeffs AG, Creese RG (2004) Bottom-drifting algal/ mussel spat associations along a sandy coastal region in northern New Zealand. Aquaculture 241:269-290

Alleway HK, Connell SD (2015) Loss of an ecological baseline through the eradication of oyster reefs from coastal ecosystems and human memory. Conserv Biol 29:795-804

Almany GR, Berumen ML, Thorrold SR, Planes S, Jones GP (2007) Local replenishment of coral reef fish populations in a marine reserve. Science 316:742-744

Andrello M, Mouillot D, Somot S, Thuiller W, Manel S (2015) Additive effects of climate change on connectivity between marine protected areas and larval supply to fished areas. Divers Distrib 21:139-150

Apte S, Star B, Gardner JPA (2003) A comparison of genetic diversity between cultured and wild populations, and a test for genetic introgression in the New Zealand greenshell mussel Perna canaliculus (Gmelin 1791). Aquaculture 219:193-220

Arnold WS, Meyers SD, Geiger SP, Luther ME, Narváez D, Frischer ME, Hofmann E (2017) Applying a coupled biophysical model to predict larval dispersal and source/sink relationships in a depleted metapopulation of the eastern oyster Crassostrea virginica. J Shellfish Res 36:101-118

Ashford J, La Mesa M, Fach BA, Jones C, Everson I (2010) Testing early life connectivity using otolith chemistry and particle-tracking simulations. Can J Fish Aquat Sci 67:1303-1315

Baker MB, Rao S (2004) Incremental costs and benefits shape natal dispersal: theory and example with Hemilepistus reaumuri. Ecology 85:1039-1051

Beck MW, Brumbaugh RD, Airoldi L, Carranza A and others (2011) Oyster reefs at risk and recommendations for conservation, restoration, and management. Bioscience 61: 107-116

Becker BJ, Levin LA, Fodrie FJ, McMillan PA (2007) Complex larval connectivity patterns among marine invertebrate populations. Proc Natl Acad Sci USA 104:3267-3272

Black KP, Bell RG, Oldman JW, Carter GS, Hume TM (2000) Features of 3-dimensional barotropic and baroclinic circulation in the Hauraki Gulf, New Zealand. N Z J Mar Freshw Res 34:1-28

Botev ZI, Grotowski JF, Kroese DP (2010) Kernel density estimation via diffusion. Ann Stat 38:2916-2957

* Brandt G, Wehrmann A, Wirtz KW (2008) Rapid invasion of Crassostrea gigas into the German Wadden Sea dominated by larval supply. J Sea Res 59:279-296

* Burgess SC, Marshall DJ (2011) Are numbers enough? Colonizer phenotype and abundance interact to affect population dynamics. J Anim Ecol 80:681-687

* Burgess SC, Treml EA, Marshall DJ (2012) How do dispersal cost and habitat selection influence realized population connectivity? Ecology 93:1378-1387

K Carson HS, Cook GS, López-Duarte PC, Levin LA (2011) Evaluating the importance of demographic connectivity in a marine metapopulation. Ecology 92:1972-1984

* Cathey AM, Miller NR, Kimmel DG (2012) Microchemistry of juvenile Mercenaria mercenaria shell: implications for modeling larval dispersal. Mar Ecol Prog Ser 465: 155-168

* Cetina-Heredia P, Roughan M, Van Sebille E, Feng M, Coleman MA (2015) Strengthened currents override the effect of warming on lobster larval dispersal and survival. Glob Change Biol 21:4377-4386

Cetina-Heredia P, Roughan M, Liggins G, Coleman MA, Jeffs A (2019) Mesoscale circulation determines broad spatio-temporal settlement patterns of lobster. PLOS ONE 14:e0211722

* Chia FS, Buckland-Nicks J, Young CM (1984) Locomotion of marine invertebrate larvae: a review. Can J Zool 62: 1205-1222

Coen LD, Brumbaugh RD, Bushek D, Grizzle R and others (2007) Ecosystem services related to oyster restoration. Mar Ecol Prog Ser 341:303-307

* Coleman MA, Roughan M, Macdonald HS, Connell SD, Gillanders BM, Kelaher BP, Steinberg PD (2011) Variation in the strength of continental boundary currents determines continent-wide connectivity in kelp. J Ecol 99:1026-1032

Coleman MA, Cetina-Heredia P, Roughan M, Feng M, Van Sebille E, Kelaher BP (2017) Anticipating changes to future connectivity within a network of marine protected areas. Glob Change Biol 23:3533-3542

Cook GS, Parnell PE, Levin LA (2014) Population connectivity shifts at high frequency within an open-coast marine protected area network. PLOS ONE 9:e103654

* Cowen RK, Lwiza KMM, Sponaugle S, Paris CB, Olson DB (2000) Connectivity of marine populations: Open or closed? Science 287:857-859

Cranford PJ, Hargrave BT, Doucette LI (2009) Benthic organic enrichment from suspended mussel (Mytilus edulis) culture in Prince Edward Island, Canada. Aquaculture 292:189-196

米Dagestad KF, Röhrs J, Breivik Ø, Ådlandsvik B (2018) OpenDrift v1.0: a generic framework for trajectory modeling. Geosci Model Dev 11:1405-1420

Dumbauld BR, Ruesink JL, Rumrill SS (2009) The ecological role of bivalve shellfish aquaculture in the estuarine environment: a review with application to oyster and clam culture in West Coast (USA) estuaries. Aquaculture 290:196-223

* Dunphy BJ, Silva C, Gardner JPA (2015) Testing techniques for tracing the provenance of green-lipped mussel spat washed up on Ninety Mile Beach. New Zealand Aquatic Environment and Biodiversity Report No. 164. Ministry for Primary Industries, Wellington

*Ehrich MK, Harris LA (2015) A review of existing eastern oyster filtration rate models. Ecol Modell 297:201-212

*Elsäßer B, Fariñas-Franco JM, Wilson CD, Kregting L, Roberts D (2013) Identifying optimal sites for natural recovery and restoration of impacted biogenic habitats in a special area of conservation using hydrodynamic and habitat suitability modelling. J Sea Res 77:11-21

FAO (2018) The state of world fisheries and aquaculture 2018-Meeting the sustainable development goals. FAO, Rome

Fariñas-Franco JM, Roberts D (2018) The relevance of reproduction and recruitment to the conservation and restoration of keystone marine invertebrates: a case study of sublittoral Modiolus modiolus reefs impacted by demersal fishing. Aquat Conserv 28:672-689

*French McCay DP, Peterson CH, DeAlteris JT, Catena J (2003) Restoration that targets function as opposed to structure: replacing lost bivalve production and filtration. Mar Ecol Prog Ser 264:197-212

*Gaines SD, White C, Carr MH, Palumbi SR (2010) Designing marine reserve networks for both conservation and fisheries management. Proc Natl Acad Sci USA 107: 18286-18293

Gausen D, Moen V (1991) Large-scale escapes of farmed Atlantic salmon (Salmo salar) into Norwegian rivers 
threaten natural populations. Can J Fish Aquat Sci 48: $426-428$

Gawarkiewicz G, Monismith S, Largier J (2007) Observing larval transport processes affecting population connectivity. Oceanography (Wash DC) 20:40-53

Gibbs MM, James MR, Pickmere SE, Woods PH, Shakespeare BS, Hickman RW, Illingworth J (1991) Hydrodynamic and water column properties at six stations associated with mussel farming in Pelorus sound, 1984-85. N Z J Mar Freshw Res 25:239-254

Giles H, Pilditch CA (2006) Effects of mussel (Perna canaliculus) biodeposit decomposition on benthic respiration and nutrient fluxes. Mar Biol 150:261-271

* Gomes I, Peteiro LG, Albuquerque R, Nolasco R, Dubert J, Swearer SE, Queiroga H (2016) Wandering mussels: using natural tags to identify connectivity patterns among Marine Protected Areas. Mar Ecol Prog Ser 552:159-176

Green AL, Maypa AP, Almany GR, Rhodes KL and others (2015) Larval dispersal and movement patterns of coral reef fishes, and implications for marine reserve network design. Biol Rev Camb Philos Soc 90:1215-1247

Hauraki Gulf Forum (2017) State of our Gulf 2014. Hauraki Gulf - Trkapa Moana/ Te Moananui a Toi. State of the environment report 2014. Hauraki Gulf Forum, Auckland

Hayden B (1995) Factors affecting the recruitment of farmed greenshell mussels Perna canaliculus, in Marlborough Sounds. MSc thesis, University of Otago, Dunedin

* Heino M, Svåsand T, Wennevik V, Glover KA (2015) Genetic introgression of farmed salmon in native populations: quantifying the relative influence of population size and frequency of escapees. Aquacult Environ Interact 6: 185-190

* Herring SC, Christidis N, Hoell A, Hoerling MP, Stott PA (2019) Explaining extreme events of 2017 from a climate perspective. Bull Am Meteorol Soc 100:S1-S117

Honkoop PJC (2003) Physiological costs of reproduction in the Sydney rock oyster Saccostrea glomerata. Oecologia 135:176-183

Inglis GJ, Hurren H, Oldman J, Haskew R (2006) Using habitat suitability index and particle dispersion models for early detection of marine invaders. Ecol Appl 16:1377-1390

Jeffs AG, Holland RC, Hooker S, Hayden B (1999) Overview and bibliography of research on the greenshell mussel, Perna canaliculus, from New Zealand waters. J Shellfish Res 18:347-360

Jensen $\varnothing$, Dempster T, Thorstad EB, Uglem I, Fredheim A (2010) Escapes of fishes from Norwegian sea-cage aquaculture: causes, consequences and prevention. Aquacult Environ Interact 1:71-83

Jochum KP, Nohl U, Herwig K, Lammel E, Stoll B, Hofmann AW (2005) GeoReM: a new geochemical database for reference materials and isotopic standards. Geostand Geoanal Res 29:333-338

Jørstad KE, Van Der Meeren T, Paulsen OI, Thomsen T, Thorsen A, Svåsand T (2008) 'Escapes' of eggs from farmed cod spawning in net pens: recruitment to wild stocks. Rev Fish Sci 16:285-295

Jouaux A, Heude-Berthelin C, Sourdaine P, Mathieu M, Kellner K (2010) Gametogenic stages in triploid oysters Crassostrea gigas: irregular locking of gonial proliferation and subsequent reproductive effort. J Exp Mar Biol Ecol 395:162-170

Kimura M, Weisss GH (1964) The stepping stone model of population structure and the decrease of genetic correlation with distance. Genetics 49:561-576
Kininmonth S, Beger M, Bode M, Peterson E and others (2011) Dispersal connectivity and reserve selection for marine conservation. Ecol Modell 222:1272-1282

KKool J, Moilanen TA, Treml EA (2013) Population connectivity: recent advances and new perspectives. Landsc Ecol 28:165-185

*KKroll IR, Poray AK, Puckett BJ, Eggleston DB, Fodrie FJ (2016) Environmental effects on elemental signatures in eastern oyster Crassostrea virginica shells: using geochemical tagging to assess population connectivity. Mar Ecol Prog Ser 543:173-186

Kroll IR, Poray AK, Puckett BJ, Eggleston DB, Fodrie FJ (2018) Quantifying estuarine-scale invertebrate larval connectivity: methodological and ecological insights. Limnol Oceanogr 63:1979-1991

* Lane DJW, Beaumont AR, Hunter JR (1985) Byssus drifting and the drifting threads of the young post-larval mussel Mytilus edulis. Mar Biol 84:301-308

* Lazareth C, Putten EV, André L, Dehairs F (2003) High-resolution trace element profiles in shells of the mangrove bivalve Isognomon ephippium: A record of environmental spatio-temporal variations? Estuar Coast Shelf Sci 57: 1103-1114

Ke Corre N, Martel AL, Guichard F, Johnson LE (2013) Variation in recruitment: differentiating the roles of primary and secondary settlement of blue mussels Mytilus spp. Mar Ecol Prog Ser 481:133-146

Le Port A, Montgomery JC, Croucher AE (2014) Biophysical modelling of snapper Pagrus auratus larval dispersal from a temperate MPA. Mar Ecol Prog Ser 515:203-215

Lipcius RN, Eggleston DB, Schreiber SJ, Seitz RD and others (2008) Importance of metapopulation connectivity to restocking and restoration of marine species. Rev Fish Sci 16:101-110

Lundquist C, Broekhuizen N (2012) Predicting suitable shellfish restoration sites in Whangarei Harbour: larval dispersal modelling and verification. Prepared for Ministry of Science and Innovation Envirolink Fund to Northland Regional Council. National Institute of Water \& Atmospheric Research, Hamilton

* Lundquist CJ, Thrush SF, Oldman JW, Senior AK (2004) Limited transport and recolonization potential in shallow tidal estuaries. Limnol Oceanogr 49:386-395

K Lundquist CJ, Oldman JW, Lewis MJ (2009) Predicting suitability of cockle Austrovenus stutchburyi restoration sites using hydrodynamic models of larval dispersal. N Z J Mar Freshw Res 43:735-748

พ Lundquist CJ, Bulmer R, Clark MR, Hillman JR and others (2017) Challenges for the conservation of marine small natural features. Biol Conserv 211:69-79

Marr JP, Baker JA, Carter L, Allan ASR, Dunbar GB, Bostock HC (2011) Ecological and temperature controls on $\mathrm{Mg} / \mathrm{Ca}$ ratios of Globigerina bulloides from the southwest Pacific Ocean. Paleoceanography 26:PA2209

McLeod IM (2009) Green-lipped mussels, Perna canaliculus, in soft-sediment systems in northeastern New Zealand. MSc Thesis, University of Auckland

*McLeod IM, Parsons DM, Morrison MA, Le Port A, Taylor RB (2012) Factors affecting the recovery of soft-sediment mussel reefs in the Firth of Thames, New Zealand. Mar Freshw Res 63:78-83

* McLeod I, Parsons D, Morrison M, Van Dijken S, Taylor R (2014) Mussel reefs on soft sediments: a severely reduced but important habitat for macroinvertebrates and fishes in New Zealand. N Z J Mar Freshw Res 48:48-59 
Morris MRJ, Fraser DJ, Heggelin AJ, Whoriskey FG, Carr JW, O'Neil SF, Hutchings JA (2008) Prevalence and recurrence of escaped farmed Atlantic salmon (Salmo salar) in eastern North American rivers. Can J Fish Aquat Sci 65:2807-2826

Morrison M, Drury J, Shanker U, Hill A (2002) A broad scale seafloor habitat assessment of the Firth of Thames using acoustic mapping, with associated video and grab sample ground-truthing. NIWA Client Report AKL-2002-014. National Institute of Water \& Atmospheric Research, Auckland

Morton JE, Miller M (1973) The New Zealand sea shore. Collins \& Sons, London

* Munday PL, Leis JM, Lough JM, Paris CB, Kingsford MJ, Berumen ML, Lambrechts J (2009) Climate change and coral reef connectivity. Coral Reefs 28:379-395

Nanninga GB, Berumen ML (2014) The role of individual variation in marine larval dispersal. Front Mar Sci 1:71

Newell RE (2004) Ecosystem influences of natural and cultivated populations of suspension-feeding bivalve molluscs: a review. J Shellfish Res 23:51-61

Nielsen P, Cranford PJ, Maar M, Petersen JK (2016) Magnitude, spatial scale and optimization of ecosystem services from a nutrient extraction mussel farm in the eutrophic Skive Fjord, Denmark. Aquacult Environ Interact 8:311-329

Nolasco R, Gomes I, Peteiro L, Albuquerque R, Luna T, Dubert J, Swearer SE, Queiroga H (2018) Independent estimates of marine population connectivity are more concordant when accounting for uncertainties in larval origins. Sci Rep 8:2641

Norrie CR (2019) Quantifying population connectivity of marine larvae: hydrodynamic modelling and shell microchemistry methods to determine larval dispersal of Perna canaliculus. PhD thesis, The University of Auckland

Norrie CR, Dunphy BJ, Baker JA, Lundquist CJ (2016) Local-scale variation in trace elemental fingerprints of the estuarine bivalve Austrovenus stutchburyi within and between estuaries. Mar Ecol Prog Ser 559:89-102

* Norrie CR, Dunphy BJ, Ragg NLC, Lundquist CJ (2019) Comparative influence of genetics, ontogeny and the environment on elemental fingerprints in the shell of Perna canaliculus. Sci Rep 9:8533

North EW, King DM, Xu J, Hood RR and others (2010) Linking optimization and ecological models in a decision support tool for oyster restoration and management. Ecol Appl 20:851-866

O'Callaghan JM, Stevens CL (2017) Evaluating the surface response of discharge events in a New Zealand GulfROFI. Front Mar Sci 4:232

Okubo A, Ebbesmeyer CC (1976) Determination of vorticity, divergence, and deformation rates from analysis of drogue observations. Deep-Sea Res 23:349-352

Oldman J, Hong J, Stephens S, Broekhuizen N (2007) Verification of Firth of Thames hydrodynamic model. Prepared for Auckland Regional Council. NIWA Client Report, National Institute of Water \& Atmospheric Research, Auckland

Palumbi SR (2003) Population genetics, demographic connectivity, and the design of marine reserves. Ecol Appl 13:146-158

Paton C, Hellstrom J, Paul B, Woodhead J, Hergt J (2011) Iolite: freeware for the visualisation and processing of mass spectrometric data. J Anal At Spectrom 26:2508-2518

Paul LJ (2012) A history of the Firth of Thames dredge fishery for mussels: use and abuse of a coastal resource. New
Zealand Aquatic Environment and Biodiversity Report No. 94. Ministry for Primary Industries, Wellington

* Petersen JK, Hasler B, Timmermann K, Nielsen P, Tørring DB, Larsen MM, Holmer M (2014) Mussels as a tool for mitigation of nutrients in the marine environment. Mar Pollut Bull 82:137-143

*Pilditch CA, Valanko S, Norkko J, Norkko A (2015) Post-settlement dispersal: the neglected link in maintenance of soft-sediment biodiversity. Biol Lett 11:20140795

Pineda J, Reyns N (2018) Larval transport in the coastal zone: biological and physical processes In: Carrier TJ, Reitzel AM, Heyland A (eds) Evolutionary ecology of marine invertebrate larvae. Oxford University Press, Oxford, p 145-163

*Pineda J, Hare J, Sponaugle S (2007) Larval transport and dispersal in the coastal ocean and consequences for population connectivity. Oceanography (Wash DC) 20:22-39

* Pineda J, Porri F, Starczak V, Blythe J (2010) Causes of decoupling between larval supply and settlement and consequences for understanding recruitment and population connectivity. J Exp Mar Biol Ecol 392:9-21

*Plew DR (2011) Shellfish farm-induced changes to tidal circulation in an embayment, and implications for seston depletion. Aquacult Environ Interact 1:201-214

* Puckett BJ, Eggleston DB (2016) Metapopulation dynamics guide marine reserve design: importance of connectivity, demographics, and stock enhancement. Ecosphere 7: e01322

พ Puckett BJ, Eggleston DB, Kerr PC, Luettich R (2014) Larval dispersal and population connectivity among a network of marine reserves. Fish Oceanogr 23:342-361

*Puckett BJ, Theuerkauf SJ, Eggleston DB Guajardo R and others (2018) Integrating larval dispersal, permitting, and logistical factors within a validated habitat suitability index for oyster restoration. Front Mar Sci 5:76

Ren J S, Ross AH (2005) Environmental influence on mussel growth: a dynamic energy budget model and its application to the greenshell mussel Perna canaliculus. Ecol Modell 189:347-362

* Ricardo F, Génio L, Leal MC, Albuquerque R, Queiroga H, Rosa R, Calado R (2015) Trace element fingerprinting of cockle (Cerastoderma edule) shells can reveal harvesting location in adjacent areas. Sci Rep 5:11932

* Sen Gupta A, Brown JN, Jourdain NC, van Sebille E, Ganachaud A, Vergés A (2015) Episodic and non-uniform shifts of thermal habitats in a warming ocean. Deep Sea Res II 113:59-72

พ Shima JS, Noonburg EG, Swearer SE (2015) Consequences of variable larval dispersal pathways and resulting phenotypic mixtures to the dynamics of marine metapopulations. Biol Lett 11:20140778

Smith RJ (2019) Settlement, retention, growth, and condition in Greenshell ${ }^{\mathrm{TM}}$ mussels (Perna canaliculus) in the Hauraki Gulf. $\mathrm{PhD}$ thesis, The University of Auckland

South PM (2016) An experimental assessment of measures of mussel settlement: effects of temporal, procedural and spatial variations. J Exp Mar Biol Ecol 482:64-74

Strasser CAA, Thorrold SRR, Starczak VRR, Mullineaux LS (2007) Laser ablation ICP-MS analysis of larval shell in softshell clams (Mya arenaria) poses challenges for natural tag studies. Limnol Oceanogr Methods 5:241-249

Strasser CA, Mullineaux LS, Walther BD (2008) Growth rate and age effects on Mya arenaria shell chemistry: implications for biogeochemical studies. J Exp Mar Biol Ecol 355:153-163 
Tettelbach S, Peterson B, Carroll J, Hughes SWT and others (2013) Priming the larval pump: resurgence of bay scallop recruitment following initiation of intensive restoration efforts. Mar Ecol Prog Ser 478:153-172

Thomas Y, Dumas F, Andréfouet S (2016) Larval connectivity of pearl oyster through biophysical modelling; evidence of food limitation and broodstock effect. Estuar Coast Shelf Sci 182:283-293

Thorrold SR, Jones GP, Hellberg ME, Burton RS and others (2002) Quantifying larval retention and connectivity in marine populations with artificial and natural markers. Bull Mar Sci 70(Suppl):291-308

Turner JS, Kellogg ML, Massey GM, Friedrichs CT (2019) Minimal effects of oyster aquaculture on local water quality: examples from southern Chesapeake Bay. PLOS ONE 14:e0224768

van der Schatte Olivier A, Jones L, Le Vay L, Christie M, Wilson J, Malham SK (2020) A global review of the ecosystem services provided by bivalve aquaculture. Rev Aquacult 12:3-25

Editorial responsibility: Megan La Peyre,

Baton Rouge, Louisiana, USA
Werner FE, Cowen RK, Paris CB (2007) Coupled biological and physical models. Oceanography (Wash DC) 20: $54-69$

* White JW, Morgan SG, Fisher JL (2014) Planktonic larval mortality rates are lower than widely expected. Ecology 95:3344-3353

*Wilcox M, Kelly S, Jeffs A (2018) Ecological restoration of mussel beds onto soft-sediment using transplanted adults. Restor Ecol 26:581-590

Wu L, Cai W, Zhang L, Nakamura H and others (2012) Enhanced warming over the global subtropical western boundary currents. Nat Clim Chang 2:161-166

* Zeldis J, Oldman RJ, Ballara SL, Richards LA (2005) Physical fluxes, pelagic ecosystem structure, and larval fish survival in Hauraki Gulf, New Zealand. Can J Fish Aquat Sci 62:593-610

zu Ermgassen PSE, Spalding MD, Grizzle RE, Brumbaugh RD (2013) Quantifying the loss of a marine ecosystem service: filtration by the eastern oyster in US Estuaries. Estuaries Coasts 36:36-43

Submitted: February 27, 2020; Accepted: May 7, 2020 Proofs received from author(s): June 10, 2020 